\title{
INFLUENCE OF SOCIO-DEMOGRAPHIC CHARACTERISTICS, FINANCIAL LITERACY AND MOOD ON FINANCIAL RISK TOLERANCE
}

DOI: 10.17261/Pressacademia.2020.1297

JBEF- V.9-ISS.3-2020(2)-p.209-222

\section{Ali Osman Oztop ${ }^{1}$, Ezgi Kuyu²}

${ }^{1}$ Mugla Sitki Kocman University, Department of Economics and Finance, Mugla, Turkey. aliosmanoztop@mu.edu.tr, ORCID: 0000-0002-7568-5927

${ }^{2}$ Mugla Sitki Kocman University, Department of Business Administration, Mugla, Turkey. ezgikuyu@mu.edu.tr, ORCID: 0000-0001-7737-6389

Oztop, A.O., Kuyu, E., (2020). Influnce of socio-demographic characteristics, financial literacy and mood on financial risk tolerance. Journal of Business, Economics and Finance (JBEF), V.9(3), p.209-222.

Permanent link to this document: http://doi.org/10.17261/Pressacademia.2020.1297

Copyright: Published by PressAcademia and limited licensed re-use rights only.

\section{ABSTRACT}

The Purpose- Risk is an inherent element of any kind of financial investment instruments. The aim of this study is to determine the factors affecting financial risk tolerance of the individuals. Additionally, this study analyses the role of mood in the financial risk tolerance.

Data and Methodology- Data were collected using a survey questionnaire. 588 questionnaires were completed and used for analysis. This study employs an ordered logit model (OLM) to validate and assess proposed research model.

Results- According to the results of the study, there is a statistically positive and significant relationship between both positive emotional state and age and financial risk tolerance. On the other hand, there is no significant relationship between gender, income, having children, financial literacy and financial risk tolerance. The results of this study indicate that the moment of decision making is important because of risk tolerance of individuals is affected by positive emotional state as well as age.

Conclusion- This study shows that both financial knowledge and positive mood are strong determinants of financial risk tolerance. Surprisingly, there is no relation between gender, income level, having children, financial literacy level and the dependent variable financial risk tolerance level. Financial risk tolerance which shapes financial decision making process is influenced by the individual's biopsychosocial and environmental factors rather than rational choice theory.

Keywords: Financial literacy, behavioral finance, mood, financial risk tolerance, ordered logit model. JEL Codes: D81, D91, G53

\section{INTRODUCTION}

Investors take expected returns of their financial instruments into consideration while making investment decision. According to traditional financial theories, investors seek to acquire maximum amount of return from their investment portfolios and these traditional theories indicate that the riskier is the investment, the greater the expected return (Tanyolac and Karan, 2015). Each investor has different preferences about their investment portfolios and portfolio selection varies with regard to their risk tolerances. As the individual's risk tolerance decreases, the risky investments he or she will make will decrease accordingly. For instance, while risk-taker investor chooses to invest in stocks, risk-averse ones prefer to investing government bonds or other lowrisk financial instruments.

Risk concept is one of the main components of financial decision making. In traditional finance, risk is specified considering the deviations from the average return and the probability of those deviations (Murgea, 2010). There is a possibility of getting returns in the amount of below or above the expected return. This possibility constitutes the risk of investment which investors made (Korkmaz and Ceylan, 2017). Investor decisions shaping the financial markets are not simple enough to confirm the assumptions of traditional finance and they are often heavily influenced by investors' psychological tendencies and biases without being based on logical bases. Especially, the fact that the individual risk perception, which is the most important factor affecting financial 
decisions, is constantly changing with the instant changes in the moods of the people, justifies the question of the existence of the rational individual concept in the finance theories (Sefil and Çilingiroğlu, 2011). Therefore, it is required to understand the determinants, which affect risk perceptions, in order to be able to understand investment decisions of individual investors. In this regard, behavioral finance focuses on psychological factors and personal attitudes unlike traditional finance theories (Lin, 2012; Pranhakaran and Karthika, 2011).

Financial risk tolerance is a term used to specify the amount of uncertainty or maximum volatility of investment return that an investor is willing to accept when making a financial decision (Grable, 2000; Grable and Joo, 2004; Grable and Lytton, 1999). Besides, according to Hallahan et al. (2003), financial risk tolerance term may be thought as opposite meaning of risk aversion concept. To be more precise, some investors are willing to take more risk in return for getting higher investment return and they are known as the investors who have higher financial risk tolerance than risk averse ones (Faff et al., 2009). On the other hand, higher financial risk tolerance comes with the possibility of potential loss or uncertain earnings (Sultana and Pardhasaradhi, 2011). Hence, it can be said that the inability to understand financial risk tolerance of investors may result in creating suboptimal portfolios (Droms, 1987).If the financial advisor chooses a portfolio inconsistent with the investor's financial risk tolerance, the investment's outcome may not be at the desired level. This disappointment is significant for both investor and investor's financial advisor and should be minimized as much as possible (Moreschi, 2005).

Understanding and measurement of investors' financial risk tolerance topics have drawn researchers' attention recently (Chavali and Mohanraj, 2016). Also, developments in financial markets and financial instruments caused to be given more importance to financial risk tolerance subject (Anbar and Eker, 2009; Kübilay and Bayrakdaroglu, 2016) because of the role of it in individuals' investment decisions and financial planning (Muzindutsi and Ramudzilu, 2016; Ryack, 2011; Yao, Gutter, and Hanna, 2005). Even in many countries, advisors in financial institutions are obliged to have some information about their investors' personal characteristics, for instance the risk perception and the risk tolerance, in order to be able to decide the most appropriate portfolio for their clients (Fisher and Yao, 2017; Grable and Roszkowski, 2008; Paradi et al., 2018; Roszkowski and Grable, 2005). According to Dalton and Dalton (2004), two common ways of understanding the risk tolerance of clients are; analyzing the investment history of the clients and using surveys to find out their opinions regarding risky and risk-free financial instruments. By the means of this information, therefore, financial advisors can create more profitable portfolios based upon each client's financial risk tolerance.

In the literature, a large amount of researches have been conducted on the subject of financial risk tolerance and its determinants (Kübilay and Bayrakdaroğlu, 2017; Moreschi, 2005), for example demographic or socio-economic characteristics, financial knowledge or investor's mood while making investment decision. As well as this, number of these studies have continued to increase substantially in recent years, however, there has not been any consensus related to the effect of these factors on financial risk tolerance (Hallahan et al., 2004).

From the demographic or socio-economic characteristics perspective; gender, job, education level, marital status, age, income level can be associated with financial risk tolerance of investors (Kumar et al., 2015). In the studies which are related with gender and financial risk tolerance, it is mostly concluded that women are less risk tolerant than men (Embrey and Fox, 1997; Pompian and Longo, 2004; Sachse et al., 2012; Thomas and Rajendran, 2012). On the other hand, relationship between the marital status and the risk tolerance topic has not been concluded clearly. Some researches indicate that single individuals have less responsibilities than married ones and they are willing to take more risk while married ones prone to choose reliable financial investments (Grable and Lytton, 1998). Therefore, according to these studies, it can be said that single individuals are more risk tolerant than married individuals (Grable and Joo, 2004). On the contrary, in some other studies, married people are more vulnerable to make risky investments because of increasing household income level (Alpay et al., 2015). In addition to these results, Alpay et al., (2015), Ceyhan (2008), Grable (2000) and Kahyaoğlu's (2011) studies concluded that there is no relationship between marital status and financial risk tolerance. In the scope of age variable, researches generally indicate that the risk tolerance decreases as one's age increases (Anbar and Eker, 2009; Jianakoplos and Bernasek, 2006). Relationship between income level and financial risk tolerance is more explicit than other determinants. When we analyze the studies in the literature, it can be seen that increasing level of income promotes individuals to invest in riskier investment tools (Brown and Taylor, 2002; Finke and Huston, 2003; Venter, 2006; Watson and McNaughton, 2007).

Financial literacy is, also, one of the determinants of financial risk tolerance (Aren and Zengin, 2016; Muzindutsi and Ramudzuli, 2015) and many studies show that financial literacy positively related with financial behavior (Mandell and Klein, 2009). Having sufficient information about financial instruments and developments may help to investors to be able to make right investment decisions (Awais et al., 2016). In the subject of mood and financial decisions relationship, although it has been accepted that mood affects general decision making and consumer behaviors (Lerner, Han, and Keltner, 2007; Lerner, Small, and Loewenstein, 2004), 
there is an on-going discussion between economists about whether the person's mood affect financial decisions (Ackert et al., 2003; Olson, 2006).

In this study, we aimed to examine whether financial literacy, mood and socio-demographic characteristics of individuals have an effect on their financial risk tolerance levels. Besides, this study is anticipated to add value to the existing literature in a suggestive way. The contribution of our research is that understanding the environmental and the biopsychosocial factors' relationship with the financial risk tolerance of investors will be helpful for the individual investors and financial advisors to make and suggest healthy investment decisions. In addition, in the next sections of the study; literature regarding financial risk tolerance and its determinants will be mentioned initially, data and methodology part will be explained in third part and then analysis and result will take place in forth section. Finally, our research's conclusion is going to be clarified in the last part of the study.

\section{LITERATURE REVIEW}

In the global financial environment, understanding the financial risk tolerance of investors is significant to be able to manage their investment wisely and therefore, as previously mentioned, financial risk tolerance and determinants of financial risk tolerance have been examined in a large number of studies still today (Moreschi, 2005). The most frequent tested variables to determine their relationship with financial risk tolerance are gender, age, marital status, number of dependents, income, wealth, education, and financial literacy (Faff et al., 2009; Gibson et al., 2013; Grable and Lytton, 1999).

Although there have been numerous studies in the field of financial risk tolerance and its determinants, different researches are not concluded with the same results, hence there is a lack of consensus on this issue (Mishra and Mishra, 2016). Some studies related to determinants of financial risk tolerance are as follows:

To understand better the determinants of financial risk tolerance, Irwin (1993) suggested the biopsychosocial and environmental factors which can have an influence on risk tolerance. Biopsychosocial factors over which the person has little or no control, for instance age, gender, personality traits and ethnicity and also environmental factors which are the factors such as socioeconomic status and family status were tested in Grable and Joo's (2004) study, based on Irwin's risk taking behavioral model. According to their study's results, education level, marital status, financial knowledge and household income that are parts of environmental factors and self-esteem that is one of the biopsychosocial factors are prominent characteristics which determine financial risk tolerance of the person. The relationship between biopsychosocial factors and financial risk tolerance was less discovered area as compared to demographic factors (Kannadhasan et al., 2016), so because of this reason, this study has an important place in the literature.

In another study which investigated effects of demographic characteristics of individual investors on financial risk tolerance, it was found that both marital status and education level were associated with financial risk tolerance and gender variable was independent from it. Moreover, while there was a low positive correlation between age and financial risk tolerance, correlation between annual income and financial risk tolerance of individual investors was observed significantly positive (Sulaiman, 2012). Wong (2011), compared three countries that comprise Australia United Kingdom and the United States in terms of financial risk tolerances and demographic factors. The study indicates that as education and income level increase, financial risk tolerance increases, as well. In contrast, risk tolerance diminishes with the age, being female and being married. Besides these, as a result of the comparison, countries whose citizens'risk tolerance levels from the highest to the lowest are Australia, the United States and finally the United Kingdom. Sung and Hanna (1997) also, found that female-headed families are less risk tolerant than maleheaded families or married ones. In addition, they concluded that gender, marital status, education level and being in different ethnic group can differentiate people in risk perception.

In the context of Sweden, Irandoust (2017) presumed to shed light on financial risk tolerance determinants of Swedish people. The research's conclusion indicates that marital status, family size, age, income, gender, financial literacy, financial stability, portfolio structure and education variables have an effect on risk seeking behavior of the person. Apart from marital status, age and dependents, other demographic determinants are positively associated with the financial risk tolerance according to this study. Nguyen et al. (2017) also examined the relationship between some demographic variables and risk tolerance of investors. While gender and income variables are associated with risk tolerance positively; age, marital status and education variables did not have the relationship with risk tolerance. According to Chavali and Mohanraj (2016), there is a gap between individual's perceived return and actual return, and this gap leads to failure in obtaining higher returns. The study says that financial risk tolerance of individuals has an impact on their decision-making process. Especially gender variable and then occupation variable have influence on risk tolerance and perception of individuals.

Thanki (2015) investigated that whether the risk tolerance depends on demographics or personality type of investors. It was concluded that both of them affect the risk tolerance. To be more precise, in demographics context, males are more risk tolerant 
than females and also unmarried investors undertake more risk than married ones. Moreover, while education has no effect on risk tolerance, income level of investor is positively related to risk tolerance. Meanwhile, it was also seen that risk tolerance has positive relationship with income to a certain level, however, risk tolerance is on the decline above that level of income. Jianakoplos and Bernasek (2006) measured the risk by observing portfolio allocations of investors and by taking their responses about their risk perceptions. According to results, risk taking decreasing with age and also households take less risk when their financial security decreases. Tanyolac and Karan (2015) analyzed the data of Income and Living Conditions Survey of Turkish Statistical Institute (TURKSTAT) between the years 2009 and 2012. As a result of the study, investors' risk tolerances and investment decisions were influenced by demographic characteristics such as age, education level, marital status and socioeconomic characteristics such as income level etc.

Another study which was implemented by multinomial probit model to examine the relationship between demographic factors and investors risk perceptions, indicates that gender and marital status have an influence on risk preferences and investment decisions (Cihangir et al., 2016). Ryack (2011), also found a relationship between gender and financial risk tolerance. According to the study, husbands are more risk tolerant than wives and in addition to this, students who have a financial education in their courses are more risk tolerant than others. Gibson et al. (2013) found that there is a positive relationship between financial risk tolerance and income level, financial investment knowledge and positive stock market expectations. Furthermore, financial risk tolerance was found lower for women and olders in this research. Moreover, in Moreschi's (2005) paper, risk tolerance scores which are based on survey results and investors' self-assessed risk tolerance scores were compared. Gender and education factors were found the most important factors for investors to forecast their own risk tolerances. This study is beneficial for financial advisors to manage their relationship with clients better. The study which were performed by Kübilay and Bayrakdaroglu (2016) tested financial risk tolerances of investors by a questionnaire. The research's conclusion indicates that investors, participated to the study, mostly are inclined to representativeness heuristic. In addition to this, while investors who largely have psychological biases were agreeable people, less frequently have psychological biases were neurotic people.

According to the Grable and Roszkowski's (2008) study results; young people, males, respondents with higher income and net worth have more risk tolerance when we compared to the others. In addition to this, the results indicated that having financial education and knowledge is related with financial risk tolerance positively. Agarwal et al. (2015) study was also concluded that high level of financial literacy is related with the better financial planning. Chaffai and Medhioub (2014) tried to clarify how psychological and emotional factors can affect stock market in Tunisia by questionnaire method. They concluded that loss aversion bias, representativeness, availability and anchoring biases are the most effective biases in Tunisian stock market and also that investors, who have high level of education (bachelor or more), are more prone to have behavioral biases. Jureviciene and Jermakova's (2012) study, also showed that Lithuanian residents overtake medium risk, and prefer safer financial investment instruments. Furthermore, they are prone to follow their friends on investment issues because of the lack of financial literacy.

Bashir et al. (2013) analyzed the effects of demographic characteristics and personality traits on financial behavioral biases and risk taking behavior. Their study's result indicated that these personality traits are significantly related with overconfidence and herd behavior and risk-taking behavior apart from disposition effect. Hallahan et al., (2004) examined the demographics and financial risk tolerances scores of participants. Gender, age, number of dependents, marital status, income and wealth were determined to be related with risk tolerance scores significantly. Calcagno and Monticone (2015) reached the conclusion that investors who have low level of financial literacy do not invest in risky assets and also they are not prone to take advices from financial consultants.

Dohmen et al. (2011) in their research, reached the conclusion that generally gender, age, and parental structure have impact on risk taking behavior. Mandal and Roe's (2014) study concluded that older individuals are less risk tolerant than young people. Also, contrary to previous studies they found that when their cognitive skills were measured, people who have lowest and highest skills display the greatest risk tolerance. De Paola (2013) asked Italian students about their risk taking willingness. According to results, women are more risk averse than men and patient ones are more risk averse while students who have higher level of competency are less risk averse. In addition to these results, students whose fathers are entrepreneurs are more prone to take risk while students whose fathers work in public sector are more risk averse. Halek and Eisenhauer (2001) investigated the demographics and risk averse relationship. At the end of the research, they concluded that in line with the existing literature, women are more risk averse than men. Also, education increases investors' risk aversion. Other variables for instance age, gender, and wealth have an effect on one's risk aversion degree. Another study in which the age and financial risk tolerance relationship was examined, has revealed that when people get older, their risk tolerance decreases. Moreover, socioeconomic environments, perceptions, demographic and economic characteristics have an impact on financial risk tolerance of investors (Yao, Sharpe, and Wang, 2011) 
Johnson and Tversky (1983) examined the investors' mood and their risk perception. They found that investors' mood affects their risky decisions even if they are not aware of that Grable and Roszkowski's (2008) research, which is about the relationship between being in positive mood and financial risk tolerance, reveals that these are positively associated with each other while Delis et al. (2015) found that happier investors are less likely to invest in risky financial investment and insurance purchases. Nguyen and Noussair (2014), also concluded that positive emotional state is positively correlated with greater risk taking. Moreover, in the study of Finucane et al. (2000), it was concluded that people who are in a good mood are prone to underestimate risks. Au et al. (2003) investigated the effects of mood on the investors' and decision makers'behavior in financial markets. They implemented two experiments and at the end of the experiment, contrary to some other studies, their study's result revealed that investors who are in a good mood gave less accurate decisions than others who are in a neutral or bad mood.

Treffers et al. (2012) examined moods as a reason for temporary risk preferences of investors. When there was no possibility to jeopardize financial incentives, sad mood caused risk aversion behavior. In addition, when the financial risks are high, mood has not important effect on risk preferences. Drichoutis and Nayga (2013) found that both negative and positive mood induce increase in risk aversion but negative mood has larger effect on increase. Moreover, some of the researchers investigated the mood which is associated with the weather and the risk attitude in the capital markets. Kliger and Levy (2003) tested if capital market investors' mood has an effect on their attitudes toward risk. According to their study's result, there is a negative correlation between mood and risk aversion. Namely, the better is the investors' mood, the more risk averse they are.

\section{DATA AND METHODOLOGY}

In this study, the determinants of financial risk tolerance is divided into three main sub-groups as financial literacy, mood and socio-demographic characteristics of individuals and it is tried to determine whether these categorical or continuous explanatory variables have an effect on individual's financial risk tolerance.

\subsection{Data}

A questionnaire was drawn up, based on the survey of risk tolerance (Grable and Lytton, 1999), financial literacy (Van Rooij et al., 2011), mood (Watson et al., 1988) and socio-demographic characteristics of individuals. Data were obtained via an internet survey. Of the study population, 588 respondents completed and returned the questionnaire.

Figure 1: The Determinants of Individual's Financial Risk Tolerance

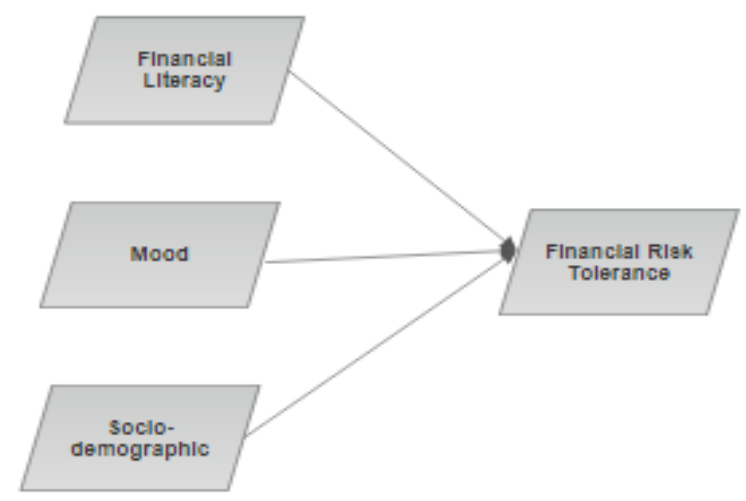

Table 1 shows the descriptive statistics of the variables. Risk tolerance survey determined participants' risk tolerance scores. Based on the results, participants are ranked with the likert-type scale range between conservative and aggressive risk tolerances suggested by (Grable and Lytton, 1999). 
Table 1: Summary Statistics

\begin{tabular}{|l|c|c|c|c|c|}
\hline Variable & Observations & Mean & Standart Deviation & Minimum & Maximum \\
\hline Risk Tolerance & 588 & 25.9795 & 4.7549 & 15 & 47 \\
\hline $\begin{array}{l}\text { Gender } \\
\text { (Female=0, Male=1) }\end{array}$ & 588 & 0.9098 & 0.2866 & 0 & 1 \\
\hline $\begin{array}{l}\text { Having Children } \\
\text { (No=0, Yes=1) }\end{array}$ & 588 & 0.8044 & 0.3969 & 0 & 1 \\
\hline Age & 588 & 29.3707 & 6.9214 & 18 & 67 \\
\hline Lnincome & 588 & 8.5 & 0.7974 & 5.991 & 11.002 \\
\hline Financial Literacy & 588 & 5.5408 & 2.7514 & 0 & 11 \\
\hline Mood (Positive) & 588 & 30.1513 & 7.3102 & 10 & 50 \\
\hline
\end{tabular}

Participants' mood states were measured by the PANAS questionnaire (Watson et al., 1988) and the positive emotion order according to their responses was formed under four groups. Gender and child ownership are dummy variables. Also note that both Age (A) and Lnincome (I) are continuous variables.

Table 2: Descriptive Statistics

\begin{tabular}{|c|c|c|}
\hline Variables & Frequency & Percent \\
\hline \multicolumn{3}{|l|}{$\begin{array}{l}\text { Dependent Variable: } \\
\text { Risk Tolerance }\end{array}$} \\
\hline Low & 31 & 5.27 \\
\hline Below & 118 & 20.07 \\
\hline Average & 257 & 43.71 \\
\hline Above & 133 & 22.62 \\
\hline High (Aggressive investor) & 49 & 8.33 \\
\hline \multicolumn{3}{|l|}{$\begin{array}{l}\text { Independent Variables: } \\
\text { Socio-Demographic }\end{array}$} \\
\hline \multicolumn{3}{|l|}{ Gender } \\
\hline Male & 535 & 90.99 \\
\hline Female & 53 & 9.01 \\
\hline \multicolumn{3}{|l|}{ Child } \\
\hline Having children (HC) & 115 & 19.56 \\
\hline No children (NC) & 473 & 80.44 \\
\hline \multicolumn{3}{|l|}{ Financial Literacy Level } \\
\hline 0 (the lowest) & 28 & 4.76 \\
\hline 1 & 33 & 5.61 \\
\hline 2 & 39 & 6.63 \\
\hline 3 & 40 & 6.80 \\
\hline 4 & 58 & 9.86 \\
\hline 5 & 72 & 12.24 \\
\hline 6 & 68 & 11.56 \\
\hline 7 & 100 & 17.01 \\
\hline 8 & 68 & 11.56 \\
\hline 9 & 48 & 8.16 \\
\hline 10 & 23 & 3.91 \\
\hline 11 (the highest) & 11 & 1.87 \\
\hline Mood (Positive) & & \\
\hline
\end{tabular}




\begin{tabular}{|l|c|c|}
\hline Very slightly or not & 62 & 10.54 \\
\hline A little & 241 & 40.99 \\
\hline Quite a bit & 235 & 39.97 \\
\hline Extremely & 50 & 8.50 \\
\hline
\end{tabular}

Table 2 shows that the vast majority of respondents are male (90.99\%). But, ordered logistic regression models do not have to meet basic assumptions such as linearity, normality, homoscedasticity, and measurement level as in linear regression models based on the ordinary least squares algorithm. In Ordinal Logistic Model (OLM), a linear relationship between the dependent and independent variables is not required. Non-linear log transformation to the predicted odds ratio in logistic regression models makes it possible to perform all kinds of relationships. In ordered logistic regression, independent variables do not need to be multivariate normal distribution and can be used without the need for important assumptions such as the variance covariance being homogeneous (Chen and Hughes, 2004).

\subsection{Methodology}

In OLM, there is a natural ordering between levels, but it does not point to the differences in the strengths of these ordinal categories of dependent variable levels. Surveys that measure behavioral psychology often take the form of a likert-type scale that covers the range from least important to most important.

OLM is a kind of multiple logistic regression model that handles ordinal dependent variable. OLM analysis is preferred to other methods used to examine the relationship between variables when the dependent variable is ordinal with more than two levels. (Grilli and Rampichini, 2014).

This analysis is based on the assumption that there is an unobservable and continuous variable behind the observable, ordinal, intermittent dependent variable (so-called latent variable). The latent variable $\left(Y^{*}\right)$ is explained by independent variables. The representation of $Y^{*}$ is as follows;

$$
Y^{*}=\sum_{k=1}^{K} \hat{b}_{k} X_{k}+\varepsilon
$$

As in the two-level dependent variable models, $Y^{*}$ can not observed and is considered as the undercurrentof unobserved phenomenon. The error term $(\varepsilon)$ is assumed to have a mean of 0 and a symmetric distribution. As the dependent variable has $\mathrm{J}$ levels of ordinal categories, the relationship between the observed levels and lines could be given as follows:

$$
\begin{aligned}
Y_{i}= & 1, Y^{*} \leq \mu_{1}(=0) \\
& Y_{i}=2, \mu_{1}<Y^{*} \leq \mu_{2} \\
& Y_{i}=3, \mu_{2}<Y^{*} \leq \mu_{3} ; \mathrm{i}=1,2, \ldots, \mathrm{N} \\
& Y_{i}=J, \mu_{J-1}<Y^{*}
\end{aligned}
$$

$\mu$ indicates the threshold values that distinguish the categories of the dependent variable from each other.

$$
p(y=j)=F\left[\mu_{j}-\sum_{k=1}^{K} \hat{b}_{k} x_{k}\right]-F\left[\mu_{j-1}-\sum_{k=1}^{K} \hat{b}_{k} x_{k}\right]
$$

Eq. (3) gives probability equations of dependent variable which has J pieces of categories. Probability equations and probabilistic expression of the logistic regression model where the dependent variable is categorized by J is given in Eq. (4).

$$
\begin{aligned}
& \log \left[\frac{P(y \leq j \backslash x)}{1-P(y \leq j \backslash x)}\right]=\mu_{j}-\sum_{k=1}^{K} \hat{b}_{k} x_{k} ; \mathrm{j}=1,2, \ldots, \mathrm{J}-1 \\
& \qquad(y \leq j)=P\left(y^{*} \leq \mu_{j}\right)=\frac{e^{\mu_{j}-\sum_{k=1}^{K} \hat{b}_{k} x_{k}}}{1+e^{\mu_{j}-\sum_{k=1}^{K} \hat{b}_{k} x_{k}}}
\end{aligned}
$$

Parallel Lines Assumption- Parallel lines assumption is the basic assumption of ordinal logit models. Accordingly, for a dependent variable that affects the likelihood that an individual will be in ordered categories, the coefficients $\left(\hat{b}_{k}\right)$ connecting variable values to different categories must be the same across all categories.

The graphical representation of the parallel lines assumption is as follows: 
Figure 2: Parallel Lines Assumption (For Four Categories Dependent Variable and a Single Independent Variable)

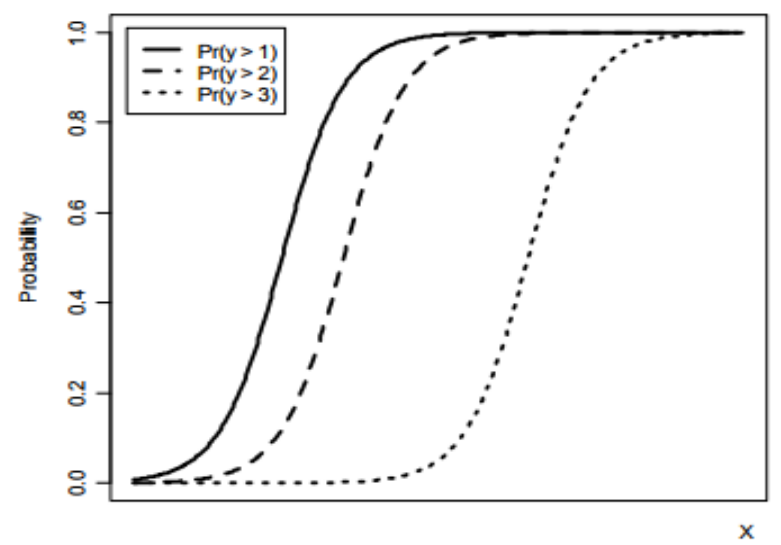

Source: Fox (2005)

Figure 2 explains that with the increase in the independent variable $X_{k}$, all three probabilities gradually approach 1 , as the lines of all three curves are the same, probability fields vary because the threshold parameters for all three probabilities differ.

\section{ANALYSIS AND RESULTS}

Model- According to the OLM results, the equation is found as follows;

$$
\sum_{k=1}^{8} \hat{b}_{k} x_{i k}=(-0.0403 A+0.1709 I+0.0357 F L+0.0413 M+0.2869 H C-1.118 V S-1.037 A L-0.5922 Q B)
$$

And the probability estimations of an individual's (i)considering the risk tolerance level are found by Eq. $(7-11)(i=1,2, \ldots, 588)$, $(k=1,2, \ldots, 8)$ :

$$
\begin{aligned}
& P\left(Y_{i}=" l o w "\right)=\frac{\exp \left(-\sum_{k=1}^{8} \hat{b}_{k} x_{k}\right)}{1+\exp \left(-\sum_{k=1}^{8} \hat{b}_{k} x_{k}\right)} \\
& P\left(Y_{i}=\text { "below" }\right)=\left\{\frac{\exp \left(1.8484 \sum_{k=1}^{8} \hat{b}_{k} x_{k}\right)}{1+\exp \left(1.8484 \sum_{k=1}^{8} \hat{b}_{k} x_{k}\right)}\right\}-\left\{\frac{\exp \left(\sum_{k=1}^{8} \hat{b}_{k} x_{k}\right)}{1+\exp \left(\sum_{k=1}^{8} \hat{b}_{k} x_{k}\right)}\right\} \\
& P\left(Y_{i}=\text { "average" }\right)=\left\{\frac{\exp \left(3.799 \sum_{k=1}^{8} \hat{b}_{k} x_{k}\right)}{1+\exp \left(3.799 \sum_{k=1}^{8} \hat{b}_{k} x_{k}\right)}\right\}-\left\{\frac{\exp \left(1.8484 \sum_{k=1}^{8} \hat{b}_{k} x_{k}\right)}{1+\exp \left(1.8484 \sum_{k=1}^{8} \hat{b}_{k} x_{k}\right)}\right\} \\
& P\left(Y_{i}=\text { "above }\right)=\left\{\frac{\exp \left(5.4348 \sum_{k=1}^{8} \hat{b}_{k} x_{k}\right)}{1+\exp \left(5.4348 \sum_{k=1}^{8} \hat{b}_{k} x_{k}\right)}\right\}-\left\{\frac{\exp \left(3.799 \sum_{k=1}^{8} \hat{b}_{k} x_{k}\right)}{1+\exp \left(3.799 \sum_{k=1}^{8} \hat{b}_{k} x_{k}\right)}\right\} \\
& P\left(Y_{i}=\text { "high" }\right)=1-\left\{\frac{\exp \left(5.4348-\sum_{k=1}^{8} \hat{b}_{k} x_{k}\right)}{1+\exp \left(5.4348-\sum_{k=1}^{8} \hat{b}_{k} x_{k}\right)}\right\}
\end{aligned}
$$

Considering the Eq. (5), the probability of the individual's risk tolerance level i. can be estimated respectively by the following equations as "low", "below", "average", "above" or "high" given below:

$$
\begin{aligned}
& P\left(Y_{i} \leq \text { "low"; } j=1\right)=P\left(y^{*} \leq \mu_{1}=0\right) \\
= & \frac{\exp \left(-\sum_{k=1}^{8} \hat{b}_{k} x_{k}\right)}{1+\exp \left(-\sum_{k=1}^{8} \hat{b}_{k} x_{k}\right)} \\
& P\left(Y_{i} \leq \text { "below"; } j=1\right)=P\left(y^{*} \leq \mu_{1}=1.8712\right)
\end{aligned}
$$




$$
\begin{aligned}
= & \left\{\frac{\exp \left(1.8484-\sum_{k=1}^{8} \hat{b}_{k} x_{k}\right)}{1+\exp \left(1.8484-\sum_{k=1}^{8} \hat{b}_{k} x_{k}\right)}\right\} \\
& P\left(Y_{i} \leq \text { "average"; } j=1\right)=P\left(y^{*} \leq \mu_{1}=3.8253\right) \\
= & \left\{\frac{\exp \left(3.799-\sum_{k=1}^{8} \hat{b}_{k} x_{k}\right)}{1+\exp \left(3.799-\sum_{k=1}^{8} \hat{b}_{k} x_{k}\right)}\right\} \\
& P\left(Y_{i} \leq \text { "above"; } j=1\right)=P\left(y^{*} \leq \mu_{1}=5.4408\right) \\
= & \left\{\frac{\exp \left(5.4348-\sum_{k=1}^{8} \hat{b}_{k} x_{k}\right)}{1+\exp \left(5.4348-\sum_{k=1}^{8} \hat{b}_{k} x_{k}\right)}\right\}
\end{aligned}
$$

\begin{tabular}{|c|c|c|c|c|c|}
\hline \multicolumn{6}{|l|}{ Dependent Variable: RiskTolerance } \\
\hline 1:Low, 2:Below,3:Average, 4:Above, 5:High & $\hat{b}$ & Std. Error & $\boldsymbol{Z}$ & $P>|z|$ & $\exp (\hat{\hat{b}})$ \\
\hline Age $(A)$ & -0.040396 & 0.0145819 & -2.77 & $0.006^{*}$ & 0.960409 \\
\hline Lnincome (I) & 0.1709317 & 0.1057103 & 1.62 & 0.106 & 1.18641 \\
\hline Financial Literacy Level (FL) & 0.0357621 & 0.0293801 & 1.22 & 0.224 & 1.036409 \\
\hline \multicolumn{6}{|l|}{ Gender } \\
\hline Male (M) & 0.4139041 & 0.2701506 & 1.53 & 0.125 & 1.512712 \\
\hline \multicolumn{6}{|l|}{ Child } \\
\hline Have child(dren) (HC) & 0.2869704 & 0.2288712 & -1.25 & 0.210 & 1.332385 \\
\hline \multicolumn{6}{|l|}{ Mood (Positive Affect) } \\
\hline Very slightly or not (VS) & -1.118018 & 0.3602724 & -3.10 & $0.002 *$ & 0.3269272 \\
\hline A Little (AL) & -1.037035 & 0.3005189 & -3.45 & $0.001 *$ & 0.3545044 \\
\hline Quite a bit (QB) & -0.5922348 & 0.2992466 & -1.98 & $0.048^{*}$ & 0.5530899 \\
\hline \multicolumn{6}{|l|}{ Threshold parameters } \\
\hline \multicolumn{6}{|l|}{$\mu_{1}=0$} \\
\hline$\mu_{2}=1.848417$ & & 0.1721977 & & $0.000^{*}$ & \\
\hline$\mu_{3}=3.799028$ & & 0.1961945 & & $0.000^{*}$ & \\
\hline$\mu_{4}=5.434859$ & & 0.2344171 & & $0.000^{*}$ & \\
\hline \multicolumn{6}{|l|}{$\begin{array}{l}\text { Likelihood ratio test for parallel lines } \\
\text { assumption }\end{array}$} \\
\hline \multicolumn{6}{|l|}{$\operatorname{chi} 2(23)=85.33($ Prob $>$ chi $2=\mathbf{0 . 0 0 0 0} *)$} \\
\hline \multicolumn{6}{|l|}{ Determining the validity of model } \\
\hline \multicolumn{6}{|l|}{ Log likelihood $=-798.45039$ LR chi2 $(8)=28.88$} \\
\hline Prob $>$ chi2 $=\mathbf{0 . 0 0 0 3} *$ Pseudo $R 2=0.0178$ & & & & & \\
\hline
\end{tabular}

Table 3: Ordered Logit Model Estimation Results

*: Coefficients are statistically significant at the $p=0.05$ level; Base categories: Female (FM), No child (NC), Extremely (EX),

Probability estimations of dependent variable- Probability estimations of five different financial risk tolerance levels were performed for each individual by means of Eq. (7-11). Figure 3 provides the graphical representation of the results. As shown in Figure 3, the predicted probabilities for the "high" and "low" tend to be less than 0.20 , with the majority of predictions for the "average" category falling between 0.40 and 0.50 . On the other hand, "below" and "above" categories tend to be between 0.10 and 0.40 . 
Figure 3: The Estimated Probabilities of Financial Risk Tolerance

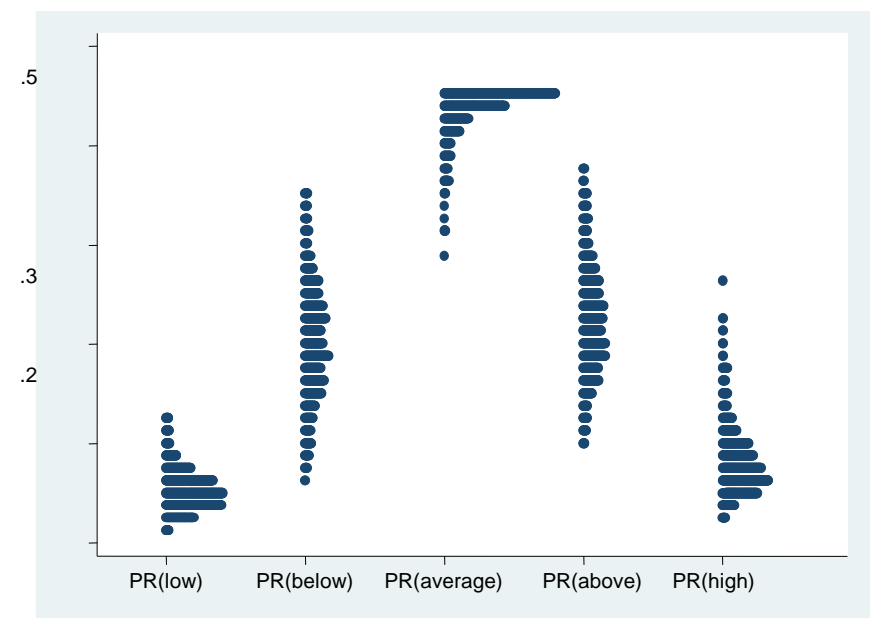

Significance test of threshold parameters- There are three threshold parameters to estimate for a five level dependent variable. As seen in the Table 3, the predicted parameters $\mu_{2}=1.848417, \mu_{3}=3.799028, \mu_{4}=5.434859$ are significant at the 0.05 significance level.

Test of the parallel lines assumption and model validity- In this study, Likelihood Ratio test was used to test the validity of parallel lines assumption. As can be seen from the Table 3, $\chi^{2}$ value 85.33 in the degrees of freedom of 23 and $p=0.0000$ which was obtained for $H_{0}$ indicates that the validity of the model assumption holds and this condition shows that OLM is a convenient approach for the modelling (Arı, 2014).

Null hypothesis for the estimated LR statistics is as follows:

$H_{0}$ : All of the regression coefficients are equal to zero and the estimated model is invalid.

The likelihood ratio $\chi^{2}$ of 798.45039 with a $p$-value of 0.0003 indicates that the model as a whole is statistically significant at a significance level of 0.05 , as compared to the null hypothesis with no predictors.

Interpretation of Coefficients and Odds Ratios- Along with the increase in the variables with statistically significant and positive coefficients, the financial risk tolerance of individuals decreases. On the other hand, with the decrease in the variables with statistically significant and negative coefficients, there is an increase in the financial risk tolerances of the individuals.

The results of the OLR analysis are shown in Table 3. From this table, we can see that there is not a statistically significant relationship between independent variables i.) financial literacy level $(t=1.22, p=0.224)$, ii.) gender $(t=1.53, p=0.125)$, iii.) having children $(t=-1.25, p=0.210)$ and iv.) income $(\log )(t=1.62, p=0.106)$ and dependent variable financial risk tolerance. On the other hand, OLR revealed that both age (A) and mood are statistically significant. From this results, we can see that $\hat{b}_{A}=-0.040396$ which indicates that for a one year increase in age, individual's ordered log-odds of being in a higher financial risk tolerance category would decrease by -0.04 while the other variables in the model are held constant. The odds ratio for age was found as $\exp \left(\hat{b}_{A}\right)=0.9604$. Since this value is not greater than 1 , the reciprocal of this value is taken to make the interpretation more clear and the value 1.041 is obtained. However, it should be noted that the "basic" and "indicator" categories are also interchanged in interpretations. Thus, for a one-year increase in age, the odds of "low financial risk tolerance" versus the combined "below, average, above and high financial risk tolerance" categories are 1.041 times greater, given the other variables are held constant in the model.

Moreover, when the levels of happiness mood are compared among themselves, those who are in the "very slightly" category are 1.07 times more likely have less financial risk tolerance than those who are in the "a little" category, and 1.88 times less financial risk tolerance than those in the "quite a bit" category. This suggests that as the happiness level increases, the likelihood of having a higher financial risk tolerance level also increases. 
The odds ratios for VS, AL and QS were found respectively as $0.326,0.354$ and 0.553 . When the reciprocal of these values is taken, respectively 3.067, 2.824 and 1.808 are obtained. Accordingly, being in an "extremely" positive mood indicates that the odds is approximately 1.808 times greater than that of individuals being in a "quite a bit" positive mood; 2.824 times greater than that of individuals being in a "a little" positive mood; and 3.067 times greater than that of individuals being in a very slightly or not" positive mood when having a "high" financial risk tolerance compared with "above" or a lesser financial risk tolerance level of individuals. This suggests that as the happiness mood level increases, the likelihood of having a higher financial risk tolerance level of individuals also increases.

\section{CONCLUSIONS}

The level of financial risk tolerance of individuals has an effect on financial decision making process. The present study was designed to determine the effect of socio-demographic factors, mood and financial literacy on individual's financial risk tolerance. Factors affecting the financial risk tolerance in the study are based on three criteria: individuals' socio demographic characteristics, financial literacy level and emotional state (i.e. positive mood).

Prior studies that have noted the importance of biopsychosocial and environmental factors effect on financial risk tolerance. According to the results of the academic studies on the determinants of financial risk tolerance, there is a positive and strong relationship between both financial knowledge and positive mood and financial risk tolerance, while there is a moderate and negative relationship between both age and income and financial risk tolerance. In addition, studies show that males have higher financial risk tolerance than females (Grable, 2016). Contrary to expectations, this study shows that there is no statistically significant relationship between independent variables gender, income level, having children, financial literacy level and the dependent variable financial risk tolerance level of individuals.

However, these findings are limited by the use of an ordinal dependent variable. Accordingly, it can be said that one of the aims of the OLM analysis is classification and investigating the relationship between variables (Mertler and Reinhart, 2016). These results therefore need to be interpreted with caution.

According to the results of the study, age and positive mood are statistically significant parameters that determine the risk tolerance behavior of individuals. This finding is in agreement with Grable and Roszkowski's (2008) findings which show that individual's happiness levels is positively associated with having a higher level of financial risk tolerance.

\section{REFERENCES}

Ackert, L. F., Church, B. K., \& Deaves, R. (2003). Emotion and Financial Markets. Economic Review - Federal Reserve Bank of Atlanta, 88(2), 33-41. http://doi.org/10.1017/CBO9781107415324.004

Agarwal, S., Amromin, G., Ben-David, I., Chomsisengphet, S., \& Evanoff, D. D. (2015). Financial literacy and financial planning: Evidence from India. Journal of Housing Economics, 27, 4-21. http://doi.org/10.1016/j.jhe.2015.02.003

Alpay, E. E., Yavuz, M., \& Kahyaoğlu, M. B. (2015). Gelir Durumunun Risk Algısına Etki Eden Diğer Sosyo-Ekonomikve Demografik Faktörler Üzerindeki Etkisi. Cumhuriyet Üniversitesi Iktisadi ve Idari Bilimler Dergisi, 16(1), 205-226.

Anbar, A., \& Eker, M. (2009). Bireysel yatırımcıların finansal risk algılamalarını etkileyen demografik ve sosyoekonomik faktörler. ZKU Journal of Social Sciences, 5(9), 129-150.

Aren, S., \& Zengin, A. N. (2016). Influence of Financial Literacy and Risk Perception on Choice of Investment. Procedia - Social and Behavioral Sciences, 235(February), 656-663. http://doi.org/10.1016/j.sbspro.2016.11.047

Arı, E.\& Yıldız, Z. (2014). Parallel Lines Assumption in Ordinal Logistic Regression and Analysis Approaches, International Interdisciplinary Journal of Scientific Research, Vol. 1, No. 3 pp. 8-23.

Au, K., Chan, F., Wang, D., \& Vertinsky, I. (2003). Mood in foreign exchange trading: Cognitive processes and performance. Organizational Behavior and Human Decision Processes, 91(2), 322-338. http://doi.org/10.1016/S0749-5978(02)00510-1

Awais, M., Laber, M. F., Rasheed, N., \& Khursheed, A. (2016). Impact of Financial Literacy and Investment Experience on Risk Tolerance and Investment Decisions: Empirical Evidence from Pakistan. International Journal of Economics and Financial Issues, 6(1), 73-79.

Bashir, T., Azam, S. N., Butt, S. A. A., Javed, S. A., \& Tanvir, S. A. (2013). Are Behavioral Biases Influenced By Demographic Characteristics \& Personality Traits? Evidence From Pakistan. European Scientific Journal, 9(29), 277-293.

Brown, S., \& Taylor, K. (2002). Wage Growth , Human Capital and Risk Preference : Evidence from the British Household Panel Survey. Retrieved April 9, 2018, from https://www.le.ac.uk/economics/research/RePEc/lec/leecon/econ02-14.pdf?uol_r=d307e306

Calcagno, R., \& Monticone, C. (2015). Financial literacy and the demand for financial advice. Journal of Banking \& Finance, 50, 363-380. http://doi.org/10.1016/j.jbankfin.2014.03.013 
Ceyhan, G. (2008). Yaşam Biçimlerinin Finansal Risk Toleransına Olan Etkileri Üzerine Bir Uygulama (Basılmamış Yüksek Lisans Tezi). Hacettepe Üniversitesi Sosyal Bilimler Enstitüsü, Ankara.

Chaffai, M., \& Medhioub, I. (2014). Behavioral finance: An empirical study of the Tunisian stock market. International Journal of Economics and Financial Issues, 4(3), 527-538.

Chavali, K., \& Mohanraj, M. P. (2016). International Journal of Economics and Financial Issues Impact of Demographic Variables and Risk Tolerance on Investment Decisions: An Empirical Analysis. International Journal of Economics and Financial Issues, 6(1), 169-175.

Chen, C. K.\&Hughes, J. (2004). Using Ordinal Regression Model to Analyze Student Satisfaction Questionnaires, Association for Institutional Research, Vol. 1, 2004, 1-13.

Cihangir, M., Şak, N., \& Bilgin, Ş. (2016). Bireysel Yatııımı Demografileri: Osmaniye Illinde Risk Getiri Tercihlerinin Multinominal Probit Modeliyle Incelenmesi. Muhasebe ve Finansman Dergisi, (70), 129-142. http://doi.org/10.25095/mufad.396684

Dalton, M. A., \& Dalton, J. F. (2004). Personal Financial Planning: Theory and Practice. Kaplan Financial.

De Paola, M. (2013). The Determinants of Risk Aversion: The Role of Intergenerational Transmission. German Economic Review, 14(2), $214-234$. http://doi.org/10.1111/j.1468-0475.2011.00561.x

Delis, M. D., Kammas, P., \& Mylonidis, N. (2015). Trust, Happiness, and Households' Financial Decisions.

Dohmen, T., Falk, A., Huffman, D., Sunde, U., Schupp, J., \& Wagner, G. G. (2011). Individual Risk Attitudes: Measurement, Determinants, and Behavioral Consequences. Journal of the European Economic Association, 9(3), 522-550. http://doi.org/10.1111/j.1542-4774.2011.01015.x

Drichoutis, A. C., \& Nayga, R. M. (2013). Eliciting risk and time preferences under induced mood states. Journal of Socio-Economics, $45,18-27$. http://doi.org/10.1016/j.socec.2013.04.008

Droms, W. G. (1987). Investment Asset Allocation for PFP Clients. Journal of Accountancy, 163(4), 114-118.

Embrey, L., \& Fox, J. (1997). Gender differences in the investment decision-making process. Journal of Financial Counseling and Planning, 8(2), 3340.

Faff, R., Hallahan, T., \& McKenzie, M. (2009). Nonlinear linkages between financial risk tolerance and demographic characteristics. Applied Economics Letters, 16(13), 1329-1332. http://doi.org/10.1080/13504850701381123

Finke, M. S., \& Huston, S. J. (2003). The Brighter Side of Financial Risk: Financial Risk Tolerance and Wealth. Journal of Family and Economic Issues, 24(3), 233-256. http://doi.org/10.1023/A:1025443204681

Finucane, M. L., Alhakami, A., Slovic, P., \& Johnson, S. M. (2000). The affect heuristic in judgments of risks and benefits. Journal of Behavioral Decision Making, 13(1), 1-17. http://doi.org/10.1002/(SICI)1099-0771(200001/03)13:1<1::AID-BDM333>3.0.CO;2-S

Fisher, P. J., \& Yao, R. (2017). Gender differences in financial risk tolerance. Journal of Economic Psychology, 61, $191-202$. http://doi.org/10.1016/j.joep.2017.03.006

Fox, J. (2005). Logistic regression. Maximum-Likelihood Estimation and Generalized Models, York Summer Programme in Data Analysis.

Gibson, R., Michayluk, D., \& Van de Venter, G. (2013). Financial risk tolerance: An analysis of unexplored factors. Financial Services Review, 22(1), 23-50.

Grable, J. E. (2000). Financial risk tolerance and additional factors that affect risk taking in everyday money matters. Journal of Business and Psychology, 14(4), 625-630. http://doi.org/10.1023/A:1022994314982

Grable, J. E., \& Lytton, R. H. (1998). Investor Risk Tolerance: Testing the Efficacy of Demographics as Differentiating and Classifying Factors. Financial Counseling and Planning, 9(1), 61-73.

Grable, J. E., \& Roszkowski, M. J. (2008). The influence of mood on the willingness to take financial risks. Journal of Risk Research, 11(7), 905-923. http://doi.org/10.1080/13669870802090390

Grable, J., \& Joo, S. (2004). Environmental and biopsychosocial factors associated with financial risk tolerance. Journal of Financial Counseling and Planning, 15(1), 73-82.

Grable, J., \& Lytton, R. (1999). Financial risk tolerance revisited: the development of a risk assessment instrument. Financial services review, 8(3), 163-181.

Grable J.E. (2016) Financial Risk Tolerance. In: Xiao J. (eds) Handbook of Consumer Finance Research. Springer, Cham. https://doi.org/10.1007/978-3-319-28887-1_2

Grilli, L., \& Rampichini, C. (2014). Ordered logit model. In Encyclopedia of Quality of Life and Well-Being Research (pp. 4510-4513). Springer Netherlands.

Halek, M., \& Eisenhauer, J. G. (2001). Demography of Risk Aversion. The Journal of Risk and Insurance, 68(1), 1. http://doi.org/10.2307/2678130

Hallahan, T. A., Faff, R. W., \& McKenzie, M. D. (2004). An empirical investigation of personal financial risk tolerance. Financial Services Review- 
Greenwich-, 13(1), 57-78.

Hallahan, T., Faff, R., \& McKenzie, M. (2003). An exploratory investigation of the relation between risk tolerance scores and demographic characteristics. Journal of Multinational Financial Management, 13(4-5), 483-502. http://doi.org/10.1016/S1042-444X(03)00022-7

Irandoust, M. (2017). Factors Associated With Financial Risk Tolerance Based on Proportional Odds Model: Evidence From Sweden. Journal of Financial Counseling and Planning, 28(1), 155-164. http://doi.org/10.1891/1052-3073.28.1.155

Irwin, C. E. (1993). Adolescence and risk taking: How are they related? In N. J. Bell \& R. W. Bell (Eds.), Adolescent Risk Taking (pp. 7-28). Newbury Park, CA: Sage.

Jianakoplos, N. A., \& Bernasek, A. (2006). Financial Risk Taking by Age and Birth Cohort. Southern Economic Journal, 72(4), 981. http://doi.org/10.2307/20111864

Johnson, E. J., \& Tversky, A. (1983). Affect, generalization, and the perception of risk. Journal of Personality and Social Psychology, 45(1), 20-31. http://doi.org/10.1037/0022-3514.45.1.20

Jureviciene, D., \& Jermakova, K. (2012). The Impact of Individuals' Financial Behaviour on Investment Decisions. In Electronic International Interdisciplinary Conference (pp. 242-250).

Kahyaoğlu, M. B. (2011). Yatırım Kararlarına Etki Eden Çeşitli Duygusal ve Psikolojik Faktörlere Maruz Kalma Düzeyi Üzerinde Cinsiyetin Rolü: IMKB Bireysel Hisse Senedi Yatırımcıları Üzerine Bir Uygulama. Ekonomik ve Sosyal Araştırmalar Dergisi, 7(1), $29-51$.

Kannadhasan, M., Aramvalarthan, S., Mitra, S. K., \& Goyal, V. (2016). Relationship between Biopsychosocial Factors and Financial Risk Tolerance: An Empirical Study. Vikalpa, 41(2), 117-131. http://doi.org/10.1177/0256090916642685

Kliger, D., \& Levy, O. (2003). Mood-induced variation in risk preferences, 52, 573-584. http://doi.org/10.1016/S0167-2681(03)00069-6

Korkmaz, T., \& Ceylan, A. (2017). Sermaye Piyasası ve Menkul Değer Analizi (8. Baskı). Bursa: Ekin Kitabevi.

Kumar, M. D., Kambuaya, M., Jamil, F., \& Muneer, S. (2015). Determinants of the Risk Tolerance of Individual Investors. International Journal of Economics and Financial Issues, 5(Special Issue), 373-378.

Kübilay, B., \& Bayrakdaroglu, A. (2016). An Empirical Research on Investor Biases in Financial Decision-Making, Financial Risk Tolerance and Financial Personality. International Journal of Financial Research, 7(2), 171-182. http://doi.org/10.5430/ijfr.v7n2p171

Kübilay, B., \& Bayrakdaroğlu, A. (2017). Finansta Psikososyal Boyut: Yatırım Psikolojisi ve SosyolojikFaktörler Açısından Bir Inceleme (1. Baskı). Ankara: Detay Yayıncılık.

Lerner, J. S., Han, S., \& Keltner, D. (2007). Feelings and Consumer Decision Making: Extending the Appraisal-Tendency Framework. Journal of Consumer Psychology, 17(3), 181-187. http://doi.org/10.1016/S1057-7408(07)70027-X

Lerner, J. S., Small, D. A., \& Loewenstein, G. (2004). Heart Strings and Purse Strings. Carryover Effects of Emotions on Economic Decisions. Psychological Science, 15(5), 337-341. http://doi.org/10.1111/j.0956-7976.2004.00679.x

Lin, H. (2012). How Herding Bias could be derived from Individual Investor Types and Risk Tolerance ? International Journal of Social, Behavioral, Educational, Economic, Business and Industrial Engineering, 6(6), 1395-1400.

Mandal, B., \& Roe, B. E. (2014). Risk tolerance among national longitudinal survey of youth participants: The effects of age and cognitive skills. Economica, 81(323), 522-543. http://doi.org/10.1111/ecca.12088

Mandell, L., \& Klein, L. S. (2009). The Impact of Financial Literacy Education on Subsequent Financial Behavior. Journal of Financial Counseling and Planning, 20(206), 15-24. http://doi.org/10.1.1.334.3320

Mertler, C. A., \& Reinhart, R. V. (2016). Advanced and multivariate statistical methods: Practical application and interpretation. Routledge.

Mishra, M., \& Mishra, S. (2016). Financial Risk Tolerance among Indian Investors: A Multiple Discriminant Modeling of Determinants. Strategic Change, 25(5), 485-500. http://doi.org/10.1002/jsc.2075

Moreschi, R. W. (2005). An Analysis Of The Ability Of Individuals To Predict Their Own Risk Tolerance. Journal of Business \& Economics Research, 3(2), 39-48.

Murgea, A. (2010). Classical and Behavioural Finance in Investor Decision. Annals of University of Craiova - Economic Sciences Series, 2(38), 212223.

Muzindutsi, P.-F., \& Ramudzilu, P. M. (2016). Financial knowledge and subjective financial risk tolerance among students at a South African university. Risk Governance and Control: Financial Markets \& Institutions, 5(3), 2015.

Muzindutsi, P.-F., \& Ramudzuli, P. M. (2015). Financial knowledge and subjective financial risk tolerance among students at a South African university. Risk Governance and Control: Financial Markets \& Institutions, 5(3), 180-185.

Nguyen, L., Gallery, G., \& Newton, C. (2017). The joint influence of financial risk perception and risk tolerance on individual investment decisionmaking. Accounting \& Finance. http://doi.org/10.1111/acfi.12295 
Nguyen, Y., \& Noussair, C. N. (2014). Risk Aversion and Emotions. Pacific Economic Review, 19(3), 296-312. http://doi.org/10.1111/14680106.12067

Olson, K. R. (2006). A Literature Review of Social Mood. The Journal of Behavioral Finance, 7(4), 193-203. http://doi.org/10.1207/s15427579jpfm0704

Paradi, J. C., Sherman, H. D., \& Tam, F. K. (2018). Financial Services Beyond Banking: Risk Tolerance Measures for Portfolio Investors (pp. 313325). http://doi.org/10.1007/978-3-319-69725-3_18

Pompian, M. M., \& Longo, J. M. (2004). A New Paradigm for Practical Application of Behavioral Finance. The Journal of Wealth Management, 7(2), 9-15. http://doi.org/10.3905/jwm.2004.434561

Pranhakaran, K., \& Karthika, P. (2011). A Study on Risk Perception and Portfolio Management of Equity Investors in Coimbatore City. Journal of Management and Science, 1(2), 1-13.

Roszkowski, M. J., \& Grable, J. (2005). Gender Stereotypes in Advisors â $€^{\mathrm{TM}}$ Clinical Judgments of Financial Risk Tolerance : Objects in the Mirror Are Closer than They Appear. Journal of Behavioral Finance, 6(4), 181-191. http://doi.org/10.1207/s15427579jpfm0604

Ryack, K. (2011). The impact of family relationships and financial education on financial risk tolerance. Financial Services Review, 20(3), 181-193.

Sachse, K., Jungermann, H., \& Belting, J. M. (2012). Investment risk - The perspective of individual investors. Journal of Economic Psychology, 33(3), 437-447. http://doi.org/10.1016/j.joep.2011.12.006

Sefil, S., \& Çilingiroğlu, H. (2011). Davranışsal Finansın Temelleri: Karar Vermenin Bilişsel Ve Duygusal Eğilimleri. Istanbul Ticaret Üniversitesi Sosyal Bilimler Dergisi, 10(19), 247-268.

Sulaiman, E. K. (2012). An Empirical Analysis of Financial Risk Tolerance and Demographic Features of Individual Investors. Procedia Economics and Finance, 2, 109-115. http://doi.org/10.1016/S2212-5671(12)00070-6

Sultana, S. T., \& Pardhasaradhi, S. (2011). An Empirical Investigation of the Relation between Risk Tolerance and Socioeconomic Characteristics of Individual Investors. QUEST-Journal of Management and Research, 2(1), 57-66.

Sung, J., \& Hanna, S. D. (1997). Factors Related to Risk Tolerance. SSRN Electronic Journal, 7. http://doi.org/10.2139/ssrn.2234

Tanyolac, C., \& Karan, M. B. (2015). Analyzing Demographic Characteristics of the Security Investors: An Application to Turkey. Journal of Economics Finance and Accounting, 2(4). http://doi.org/10.17261/Pressacademia.2015414376

Thanki, H. (2015). Risk Tolerance Dependent on What ? Demographics or Personality Type : Findings from an Empirical Research. Journal of Marketing and Consumer Research, 6, 48-56.

Thomas, T. C., \& Rajendran, G. (2012). BB \& K Five-way Model and Investment Behavior of Individual Investors : Evidence from India. International Journal of Economics and Management, 6(1), 115-127.

Treffers, T., Koellinger, P. D., \& Picot, A. O. (2012). In the Mood for Risk? An Experiment on Moods and Risk Preferences. ERIM Report Series Research in Management, (July).

Van Rooij, M. C., Lusardi, A., \& Alessie, R. J. (2011). Financial literacy and retirement planning in the Netherlands. Journal of Economic Psychology, 32(4), 593-608.

Venter, G. V. (2006). Financial Planners' Perceptions of Risk Tolerance. In The 2006 Financial Management Association's (FMA) Annual Conference (pp. 1-31). Salt Lake City, Utah, USA.

Watson, D., Clark, L. A., \& Tellegan, A. (1988). Development and validation of brief measures of positive and negative affect: The PANAS scales. Journal of Personality and Social Psychology, 54(6), 1063-1070.

Watson, J., \& McNaughton, M. (2007). Gender Differences in Risk Aversion and Expected Retirement Benefits. Financial Analysts Journal, 63(4), 52-62. http://doi.org/10.2469/faj.v63.n4.4749

Wong, A. (2011). Financial Risk Tolerance and Selected Demographic Factors : A Comparative Study in 3 Countries. Global Journal of Finance and Banking Issues, 5(5), 1-13.

Yao, R., Gutter, M. S., \& Hanna, S. D. (2005). The Financial Risk Tolerance of Blacks, Hispanics and Whites. Financial Counseling and Planning, 16(1), 51-62.

Yao, R., Sharpe, D. L., \& Wang, F. (2011). Decomposing the age effect on risk tolerance. Journal of Socio-Economics, 40(6), 879-887. 